\title{
Literatura wizualna, wizualność literatury - przegląd współczesnych zjawisk i tendencji
}

Streszczenie. Celem artykułu jest prezentacja przeglądu najistotniejszych nurtów, jakim przez ostatnie stulecie podlegał tekst literacki o walorach wizualnych. Z punkt wyjścia przyjęto okres przełomu XIX i XX wieku, gdy pod wpływem działań artystów awangardowych (Guillaume Apollinaire, Stéphane Mallarmé) nastąpiły zmiany w postrzeganiu semantycznego znaczenia poezji, co doprowadziło do sytuacji, w której wizualna struktura tekstu stała się istotna (wspomniane zostały prace m.in.: F.T. Marinettiego, T. Czyżewskigo, L. Chwistka). Zainteresowanie nowoczesną typografią wykazywali w okresie tuż po I wojnie światowej i w międzywojennym okresie wielkiej awangardy artyści związani z dadaizmem i polską grupą „a.r”. Kolejny istotny moment we wzajemnych relacjach tekstu i plastyki to okres lat 60. XX wieku i „poezji konkretnej” (E. Gomringer, bracia de Campos czy S. Dróżdż, tworzący tak zwane „pojęciokształty”). W XXI wieku emanacja działań łączących ściśle poezję ze sztukami wizualnymi to literatura elektroniczna, czyli electronic literature, określana mianem cyfrowej lub HTML, oraz liberatura (K. Bazarnik, Z. Fajfer, R. Nowakowski).

Słowa kluczowe: typografia, awangarda, literatura, sztuka polska XX w., literatura elektroniczna.

\section{Stan badań}

adanie pogranicza ze zjawisk tekstu i sztuk wizualnych znalazło się początkowo w orbicie zainteresowań głównie kuratorów muzealnych takich jak Jasia Reichardt - organizatorka słynnej londyńskiej wystawy „Between Poetry and Painting" z roku $1965^{1}$. Dopiero w latach 70. XX wieku pojawily się 
teksty podsumowujące zjawisko poezji konkretnej autorstwa semiotyków i estetyków, takich jak Max Bens czy Eugen Gomringer². Do Polski analiza zjawisk z pogranicza literatury i malarstwa dotarła w latach 80 . XX wieku. Wymienić tu należy publikacje Janiny Wiercińskiej Szuka i książka oraz nieco późniejszą pozycję autorstwa Piotra Rypsona Obraz słowa. Historia poezji wizualnej. Jeśli chodzi o wiek XXI, na uwagę zasługuje zwłaszcza zainteresowanie badaczy internetową literaturą włączającą do swego imaginarium znak graficzny. Tym zagadnieniom poświęcony jest portal Eliterature (http://eliterature.org/people/), ale też i liczne strony związane z Korporacją Ha!art (np. http://ha.art.pl/).

\section{Wizualność $w$ literaturze - problemy z definicją}

Termin literatura wizualna jest pojęciem szerokim i obejmuje olbrzymią ilość tekstów, autorów, motywacji, celów i programów estetycznych. To typ wypowiedzi literackiej, w której poeta/pisarz zwiększa rolę wizualnej formy tekstu docelowego: elementów ikonograficznych, typograficznych kolaży, spacjowania, pogrubienia, zagęszczenia druku, krojów pisma, wersalików i kursywy. Jej przykłady znajdujemy już w starożytności (np. hellenistyczne kaligramy z IV wieku określane mianem technopaegnia ${ }^{5}$ ) i literaturze dawnej - od średniowiecznych manuskryptów ilustrowanych po XIX-wieczny nurt beautiful books, którego orędownikiem była oficyna wydawnicza Kelmscott Press założona przez Williama Morrisa ${ }^{6}$.

W wieku XX układ typograficzny stał się tak samo ważny jak znaczenie słów, rym i rytm w tradycyjnej poezji. Dziś literatura wizualna jest kojarzona także z najnowszymi praktykami artystycznymi obejmującymi takie zjawiska jak liberatura i literatura hipermedialna.

Za początek rozważań przyjmuję futuryzm, jednakże historia działań, w których nie tylko słowa traktuje się jako budulec literackich prac, ale eksperymentuje z nim na polu wizualnym (a często też dźwiękowym), sięga końca XIX wieku. Za pionierów tych praktyk można uznać np. Lewisa Carrolla (1832-1898), Stéphane’a Mallarmégo (1842-1898) czy Guillaume’a Apollinaire’a (1880-1918). Na uwagę zasługują zwłaszcza dwaj ostatni poeci.

Poemat Rzut kośćmi nigdy nie zniesie przypadku (Un coup de Dés jamais n’abolira le Hasard) autorstwa Mallarmégo już w momencie powstania był przełamaniem klasycznych zasad retoryki. Poeta obrzucił w nim poezję zarówno o charakterze dyskursywnym jak i deskryptywnym, rezygnując tym samym z prostego opisu

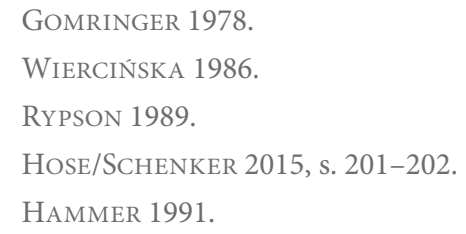




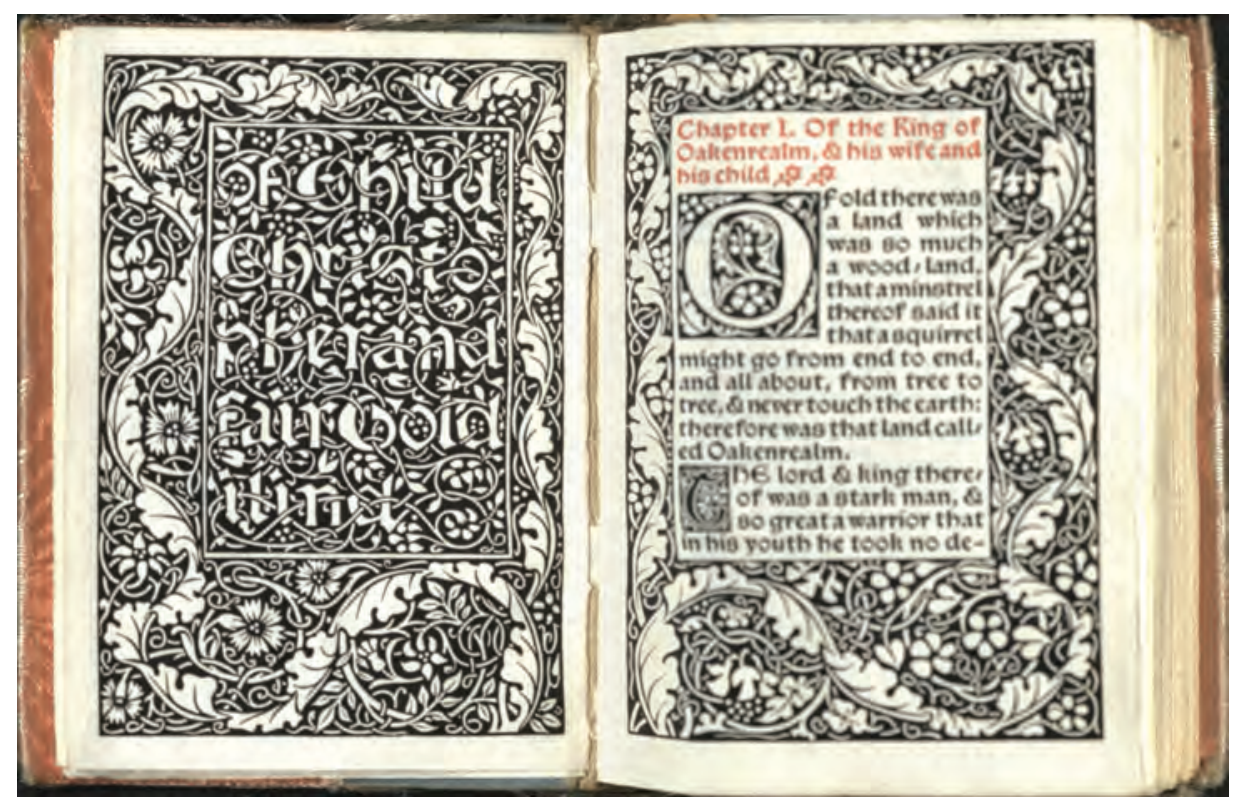

1. Strona tytułowa Child Christopher and Goldilind the Fair, Wydawnictwo Kelmscott Press, 04-13988 Fine Print, John J. Burns Library, Boston College

rzeczywistości. Jego istotą stał się język, rozpatrywany także od strony struktury wizualnej zapisywanych słów. Było to zgodne z deklaracjami „poety wyklętego” z eseju pt. Książka, narzędziem duchowym (1895), gdzie podkreślał znaczenie „rytuału składu typograficznego" . Warto dodać, iż artysta miał duże oczekiwania wobec sposobu, w jaki wiersz ma być wydrukowany. Otóż chciał, by przyjętą jednostką druku nie była typowa pojedyncza strona, narzucająca tradycyjną lekturę od lewego do prawego marginesu oraz z góry na dół. Poeta uznał, że wertykalny porządek należy zastąpić horyzontalnym, by jednostką miary stały się dwie strony, bo - jak pisał dalej w liście do André Gide’a - „to w paginacji kryje się cały efekt”. Dlatego nie był do końca usatysfakcjonowany pierwszym wydaniem Rzutu kośćmi w piśmie „Cosmopolis” z 1897 roku. Zapewne dopiero drugie wydanie wiersza przez Ambroise’a Vollarda powstałe we współpracy z drukarzem Firminem Didotem nakładem Éditions de la Nouvelle Revue française w 1914 roku mogłoby w pełni zadowolić poetę (niestety już wówczas nie żył) ${ }^{9}$. O wkładzie tego utworu w rozwój koncepcji współczesnej literatury wizualnej świadczy także fakt, iż doczekał się wznowienia w serii Ha!artowskiej liberatury ${ }^{10}$ (do tematu za chwilę powrócę).

\footnotetext{
Mallarmé 1980, s. 89.

8 Cyt. za: ŚNIEDZIEWSKi 2010, s. 195.

9 Ibidem, s. 195-196.

10 Mallarmé 2005.
} 


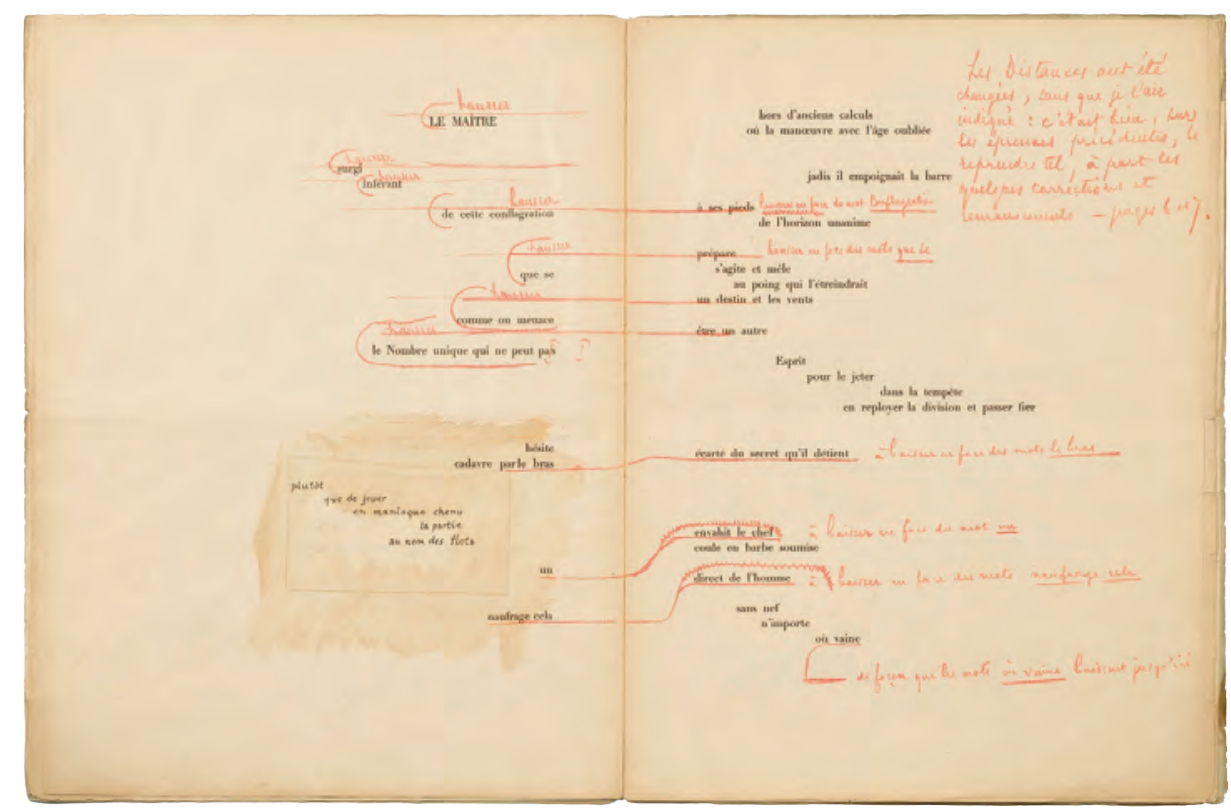

2. Rzut kośćmi, próbny wydruk w edycji Ambroise Vollard z poprawkami Mallarmégo, lipiec 1897, Biblioth que nationale de France (Wikisource)

Równie przełomowe znaczenie dla literatury wizualnej ma zbiór wierszy Kaligramy (Calligrammes 1918) - Guillaume’a Apollinaire’a. To w nim twórca najpełniej zaznaczył nowatorstwo oryginalnych koncepcji poetyckich dopełnionych nowoczesnym bezrymowym wierszem wolnym o niezwykle wyrafinowanych strukturach graficznych. W takich utworach jak: Lettre-Océan, La Colombe Poignardée et le Jet d'Eau, Il pleut ${ }^{11}$, La petite auto, Cheval, Cour, couronne et miroir sens tekstu znajduje odzwierciedlenie w przestrzennym układzie wersów.

Działalność wszystkich wyżej wymienionych twórców cechuje przełomowy układ form ich utworów, rozbijający skostniałą historyczną strukturę języka, tak by dostosować go do zachodzących przemian społeczno-kulturowych. Rewolucja przemysłowa i rozkwitający kapitalizm wpłynęły na postępującą tendencję w kierunku ujednolicenia i masowości, a także stworzyły na początku XX wieku szczególną rzeczywistość.

\section{Parole in libertá - włoscy futuryści}

Najwyraźniej potrzebę koniecznych zmian w obrębie literatury i sztuk wizualnych zauważyli artyści związani z futuryzmem. Byli oni wyczuleni na nową energię związaną z miastem i techniką, toteż postulowali stworzenie współczesnego języ-

\footnotetext{
11 W utworze Il Pleut (Pada deszcz) Apollinaire’a pokazany został proces spływania/spadania liter jako kropli wody po szybie. Bardzo ciekawa współczesna animacja tego wiersza znajduje się na stronie http://www.eratiopostmodernpoetry.com/editor_Il_Pleut.html [dostęp: 20 grudnia 2018].
} 
ka odrzucającego klasyczne układy i wzory. Ów język był nastawiony na poetykę dźwięku, a nie na treść. Nowa stylistyka koncentrowała się przede wszystkim na odrzuceniu przymiotników, przysłówków i znaków przestankowych, zaprzeczeniu dawnym porządkom składni oraz wprowadzeniu nowej typografii. Szczególne miejsce przypadło onomatopei, instrumentacji głoskowej - paronomazji czy annominacji, które stały się literackimi odpowiednikami nowatorskich środków plastycznych wyobrażających ruch, rytm i możliwości nowoczesnej techniki np. elektryczne światło. Już w roku 1909 włoski poeta, piszący także po francusku, Filippo Tommaso Marinetti (1876-1944) i jego liczni naśladowcy głosili w „jednodniówkach” i manifestach hasła wypisane w różnych językach parole in libertá - „słowami na wolności” (taki tytuł nosił manifest Marinettiego z roku 1913 roku, postulujący wspomniane powyżej oswobodzenie literatury z rygorów składni języka i konwencjonalnego składu drukarskiego) ${ }^{12}$. W tym samym roku Marinetti wprowadził do kanonu literackiego notację matematyczną oraz tablice synoptyczne „słów na wolności”: litery i wyrazy zostały rozrysowane na stronie różnymi czcionkami i w geometrycznych układach. Można uznać, iż założenia futurysty związane ze „słowami na wolności” powodowały niską przewidywalność syntaktyczną i znaczeniową, dlatego otwarły drogę do „wyobraźni bez łączników”. Za podstawę poetyckiej ekspresji Marinetti przyjął enharmonię liter oraz kakofonię dźwięków, sylab i wyrazów ${ }^{13}$. Jak pisał międzywojenny entuzjasta takiej formuły artystycznej:

„Parole in liberta” oddają kolory, zapachy, hałasy, dźwięki, formuły geometryczne i arytmiczne, ryki zwierząt, turkoty motorów, archaizmy, barbaryzmy, egzotyzmy i neologizmy językowe! Słowem wszystko! Zwycięstwo artystyczne „parole in liberta" dzieli historję poezji na dwie epoki: epokę Homera i epokę futuryzmu ${ }^{14}$.

Do najbardziej reprezentatywnych przykładów realizacji tej idei należy tom poezji samego Marinettiego Zang Tumb Tumb (1914), w którym wyzwoloną z wszelkich ograniczeń ( $\mathrm{z}$ wyjątkiem typowej kodeksowej budowy książki) typografię uznać można za pełnoprawny środek wyrazu, a samą książkę za jeden z wybitnych przejawów twórczości artystycznej tamtych lat, rozsadzającej ramy społecznych ograniczeń i ustalonego porządku. Zaprzeczenie dawnym porządkom składni, wprowadzenie innej typografii, gdzie szczególną rolę odgrywała onomatopeja czy paronomazja, miały stać się literackim i plastycznym odpowiednikiem codzienności. „Malarze-futuryści używali okaleczonych sylab jako elementów wprowadzających wrażenie dźwiękowego hałasu”"15.

\footnotetext{
MARINETTI 1913.

MiCZKA 1994, s. 78.

Boyé 1926, s. 1.

15 RYPSON 1989, s. 257.
} 
TECHNE

T E X N H

SERIA NOWA

\section{"Słowa na wolności" w całej Europie}

Wkrótce badania nad funkcją języka skorelowanego z przypisanym mu znakiem oprócz Włoch objęły również inne kraje. Jak zauważył ex post jeden z ówczesnych polskich awangardzistów -Aleksander Wat: „Starczyło jedno hasło, jedno małe odkrycie, jedno zdanie składające się z trzech wyrazów: «słowa na wolności». (...)”16. W Rosji sięgnęli po nowe możliwości kryjące się w literaturze wizualnej tacy artyści jak Włodzimierz Majakowski, Kazimierz Malewicz (1879-1935), Wielimir Chlebnikow (1885-1922) czy Korniej Czukowski (1882-1969). Za najbardziej spektakularny przykład współpracy poety z plastykiem z tego okresu można uznać dzieło francuskiego poety szwajcarskiego pochodzenia Blaise’a Cendrarsa (1887-1961), zatytułowane Proza transsyberyjskiej kolei i małej Żanny z Francji (La Prose du Transsibérien et de la Petite Jehanne de France). Pierwsze wydanie poematu, zaprojektowane przez francusko-rosyjską malarkę Sonię Delaunay (1885-1979) i opublikowane w 1913 roku $^{17}$. Książka o kształcie harmonijki złożonej z 22 segmentów, podzielona została na dwie kolumny o jednakowej szerokości. Ponad dwumetrowy arkusz zajmował nie tylko wiersz, drukowany 12 rodzajami czcionek, lecz także usytuowane po lewej stronie barwne grafiki. Twórcy zakładali, że lektura książki w warstwie tekstu i obrazu będzie odbywała się symultanicznie, a poezja, malarstwo i budowa książki będą przenikały się tworząc nową jakość artystyczną. Niestety późniejsze edycje poematu były wznawiane w tradycyjnej w formie.

Z kilkuletnim opóźnieniem idee futurystyczne dotarły również do Polski, objawiając swoje istnienie prowokacyjnymi manifestami i obrazoburczymi, nastawionymi na skandal tomikami poezji, celowo drażniącymi mieszczańskiego odbiorcę łamaniem reguł ortografii i gramatyki oraz nietypowym zastosowaniem elementów graficznych czy krzykliwą kolorystyką okładek. W Polsce fascynację nową typografią głosili jako pierwsi Brunon Jasieński (1901-1938), Stanisław Młodożeniec (1895-1959), Aleksander Wat (1900-1967) i Anatol Stern (1899-1968). W jednodniówkach futurystycznych pojawiały się przekształcenia ortografii na zapis fonetyczny (Nuż w bżuhu. 2 jednodńuwka futurystów. Wydanie nadzwyczajne), kładziono nacisk na rytm i rym ${ }^{18}$.

Z okresu tego należy też przywołać manifestacyjne komentarze futurysty i formisty Tytusa Czyżewskiego (1880-1945) z roku 1921, które znalazły odzwierciedlenie w jego poezji - ujmującej świat architektonicznie, w diagramach wizualno-słownych przedstawiającej rzeczywistość wielozmysłową, a także w poezji o „instynkcie mechanicznym" - prezentującej przenikające się jednocześnie sfery biologii i auto-

\footnotetext{
16 WAT 1990, s. 27.

17 Cendrars 2006, s. 299.

18 Jako jedna pierwszych eksperymenty typograficzne polskich futurystów analizowała Bożena Lewandowska (LEWANDOWSKA 1966, s. 192-283).
} 
matyki. Jak pisał: „Poezja współczesna musi sobie stworzyć nową odrębną formę, podatną dla ludzi współczesnych, łaknących nerwowych, syntetycznych wzruszeń (...). Artyści będą jak najmniej używać tematu, a jak najwięcej konstruować” ${ }^{19}$.

Czyżewski, mimo nieświadomości mających nastąpić dekady później rewolucji technologicznych, wspomina o człowieku XXI wieku, przewidując rzeczywistość całkowicie zdominowaną przez urządzenia elektroniczne (z czym mamy do czynienia w literaturze HTML, o której będzie mowa). Dlatego jego wiersze o specyficznym rytmie zachęcają współczesnych twórców do cyfrowego ujęcia. Wielozmysłowość i losowość pojawiają się w licznych utworach powstałych w latach 1917-1922 - na przykład w Oczach tygrysa, matematyczność w Poemacie liczb, powtórzeniowość w Muzyce z okna, symultaniczność W szpitalu obłakanych, przestrzenność w Hymnie do maszyny mego ciała, zaś wielopłaszczyznowość w Nocy - dniu ${ }^{20}$. Można dodać, iż często zabiegi Czyżewskiego kompozycyjne dokonywane na własnych wierszach dziś są traktowane jako szczegółowe wskazówki do realizacji nowej cyfrowej wersji tychże poematów. Warto też przytoczyć komentarz innego formisty - Leona Chwistka (1884-1944) na temat poezji Czyżewskiego, który jednocześnie stanowi doskonały opis literatury wizualnej: „pokonuje treść przez zestawianie zdań prostych, zaczerpniętych najczęściej z świata wrażeń wzrokowych w ten sposób, żeby słuchacz nie mógł doszukać się pomiędzy nimi myślowego związku”21.

\section{Dadaiści - międzywojenna awangarda}

Pomysłowością w komponowaniu fantazyjnych układów typograficznych i wynajdywaniu nowych form ekspresji futurystycznym piewcom nowoczesności dorównywali ironiczni piewcy chaosu - dadaiści, stanowiący równie międzynarodowe towarzystwo. Członkowie tego ruchu wyżywali się zarówno w twórczości indywidualnej, jak i zespołowej, głównie na łamach zuryskiego pisma „Dada”, redagowanego przez rumuńskiego poetę Tristana Tzarę (1896-1963), oraz „391”, wydawanego w Barcelonie, a później w Zurychu i Paryżu przez hiszpańskiego malarza Francisa Picabię (oba pisma ukazywały się od roku 1917)22. Nie mniej intrygujące formą zapisu, a przy tym niezwykle zabawne w głośnym wykonaniu były prezentowane w słynnym Cabaret Voltaire poematy symultaniczne wspólnego autorstwa Tzary, Marcela Janco i Richarda Huelsenbecka (po raz pierwszy w 1916 roku $^{23}$. Interesujące były także prace Raoula Hausmanna (1886-1971) - austriackiego dadaisty związanego ze środowiskiem berlińskim, niezawierające „słów”, lecz układy typograficzne znaków, w których

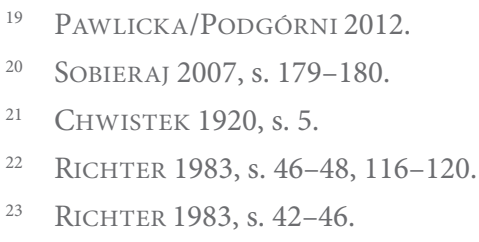


„stosowanie liter różnej wielkości, dużych i małych, cienkich i wytłuszczonych, tworzyło coś w rodzaju zapisu muzycznego"24. Hausmann posunął się najdalej w swoich działaniach - tworzył poematy plakatowe (niem. Plakatgedichten), takie jak O F F E A H B D C oraz $f m s b$ w $\ddot{o} z \ddot{a} u$ (obydwie prace z $1918 \mathrm{roku}$ ). Artysta nowatorsko połączył optykę i fonetykę, czyniąc tym samym poezję materiałem optofonetycznym. Swoją metodę przechodzenia od obrazu do dźwięku (i odwrotnie) opatentował w 1936 roku pod nr 446338 25 . Zasięg działań futurystów i dadaistów objął całą międzywojenną Europę (m.in. Rumunię, Jugosławię, Holandię).

W międzywojennym okresie wielkiej awangardy na szczególną uwagę zasługują pionierskie dokonania w zakresie liternictwa i tzw. druku funkcjonalnego Władysława Strzemińskiego (1893-1952) 26. Strzemiński był czołową postacią polskiej awangardowej grupy „a.r.”, w której nowa plastyka i nowa poezja były uzupełniającymi się częściami tego samego zjawiska artystycznego, stając się źródłem inspiracji współczesnych rozwiązań typograficznych. Stworzenie książki, w której zostałyby wykorzystane środki wizualnego oddziaływania, nowego systemu recytacji kreowanej wzrokiem, było zadaniem niezwykle ważnym dla Strzemińskiego. Chciał przeciwstawić nową koncepcję układu typograficznego tradycyjnym wydaniom utworów poetyckich, ograniczających rolę plastyka do tworzenia dekoracyjnych ornamentów. Dlatego starał się w kolejnych listach przygotować i przekonać współpracującego z nim poetę Juliana Przybosia do wprowadzenia prekursorskiego rozwiązania polegającego na „myśleniu wzrokiem”27. Tak zakomponowane zostały wiersze wchodzące w skład tomu poezji Przybosia $Z$ Ponad. Strzemiński zaproponował poecie budowę wszystkich utworów „według jednolitej skali obliczeniowej”, podporządkowanej układowi linii pionowych i poziomych o „jednakowej grubości $3 \mathrm{~mm}^{\prime 28}$. Ponadto wprowadzał odpowiadające słownej dynamice typograficzne sygnały wizualne, jedyny komponent tekstu oprócz ostro uwydatnianych zestawień czcionek; strofy wiersza zostały rozłożone według zawartych w nich myśli na szereg odrębnych zespołów oznaczonych liniami, skontrastowanych różnym rodzajem pisma i wielkością liter. Forma typograficzna miała wzmocnić przekaz zawartej w niej treści ${ }^{29}$.

\footnotetext{
24 Ibidem, s. 213-214.

25 Weibel 2005, s. 83.

26 Artyści zajmujący się zagadnieniem druku funkcjonalnego w dwudziestoleciu międzywojennym to m.in.: Gustaw Kłucis, Enrico Prampolini, Aleksander Rodczenko, Xanti Schawinsky, Joost Schmidt, Kurt Schwitters, Henryk Stażewski, Władysław Strzemiński, Ladislav Sutnar, Mieczysław Szczuka, Karel Teige, Jan Tschichold (Zmiana Pola Widzenia 2014).

27 TurowsKi 1973, s. 227.

28 Ibidem.

29 Szczegółowa analiza złożonego konceptu malarza przekroczyłaby ramy tematyczne zakreślone w tytule artykułu. Szerzej: TUROWSKi 1973.
} 
W kręgu polskiego konstruktywizmu na uwagę zasługują także specyficzne, a mało znane plakaty autorstwa Edmunda Millera zaprezentowane w 1921 roku $^{30}$ w Polskim Klubie Artystycznym, który mieścił się w warszawskim hotelu Polonia, uchodzącym za jeden z najbardziej eleganckich i nowoczesnych w Warszawie. Plakaty, w których - jak zauważał anonimowy recenzent - „środkami plastyko-graficznymi, faktycznie u nas dotychczas niewykorzystanymi dostatecznie", artysta uzyskać chce „sens wewnętrzny wyrazów”, stosując „przestankowanie, grupowanie i pisanie większymi i mniejszymi znakami” oraz używając do tego „różnych barw dla silniejszej ekspresji i znaczenia symbolicznego stosunku zdań”, by wyrazić „pewną harmonię dźwiękową i pewien bardzo prymitywny rytm"31.

\section{Poezja konkretna}

Doświadczenie modernizmu sprzed II wojny światowej dało mocne fundamenty do dalszej analizy słowa, co skwapliwie wykorzystano w drugiej połowie XX wie$\mathrm{ku}$, tworząc nowy gatunek sztuki, jakim jest poezja konkretna. Sam termin powstał w 1955 roku, kiedy to dwóch artystów, Szwajcar Eugen Gomringer i Brazylijczyk Décio Pignatari, spotkało się w Ulm i określiło mianem „poezji konkretnej” wspólne projekty. Warto zaznaczyć, że termin „konkretny” zaczerpnięty został od holenderskiego malarza Theo van Doesburga (1883-1931), który w Manifeście sztuki konkretnej (Manifesto of Concrete Art, 1930) odniósł go do metod malarskich polegających na prezentowaniu przedmiotu wyłącznie dzięki środkom stosującym formy geometryczne, głównie obejmującym elementy sztuki abstrakcyjnej i konstruktywizmu. Od lat 50. XX wieku pod tą nazwą kryją się działania dążące do uwolnienia słowa od czynników zewnętrznych i pozbawienia go indywidualnych konotacji. Za najważniejszych animatorów ruchu „konkretystycznego” uchodzą (poza wymienionymi powyżej Gomringerem i Pignatarim) Szwed Öyvind Fahlström (Manifest för konkret poesie, 1953) oraz skupieni w grupie Noigandres bracia Augusto i Haroldo de Campos z Brazylii (Plano-piloto para poesia concreta, 1958). Wszyscy oni kładli nacisk na te same podstawowe elementy: literę (pojedynczy znak) i słowo w ich wymiarze fizykalnym, wyzwolonym nie tylko z zasad syntaktyki i semantyki, ale i z wszelkiej referencyjności. Czasem pojawiały się izolowane brzmienia jak w przypadku poezji fonicznej, określanej mianem „muzyki konkretnej”32. Nawiązując w swych manifestach do twórczości François Rabelais, Carrolla, Mallarmégo, E.E. Cummingsa, Ezry Pounda, Jamesa Joyce’a, konkretyści posługiwali się motywami określanym jako „konstelacje słów”33, podkreślając tym samym wagę czasoprzestrzennej organizacji

\footnotetext{
Była to wspólna wystawa Henryka Stażewskiego, Mieczysława Szczuki i Millera. 
tekstu tworzonego przez „słowo-przedmioty”34. W działaniach tych chodziło, jak określił to niemiecki semiotyk, pisarz, teoretyk konkretyzmu Max Bense:

o stworzenie zespołów słów, które jako całość stanowią werbalną, wokalną i wizualną przestrzeń przekazu, trójwymiarowe ciało języka, ciało to zaś jest nosicielem własnego szczególnego konkretnego „estetycznego przesłania” ${ }^{\text {”5 }}$.

Następne dziesięciolecia to moment prawdziwego triumfu poezji konkretnej, która stała się ruchem o międzynarodowym zasięgu (wymienić tu można chociażby twórczość Amerykanki Mary Ellen Solt, Szkota Iana Hamiltona Finlaya, członków Grupy wiedeńskiej, Czechów Jiřía Kolařa i Eduarda Ovčáčka). Warto w tym momencie przywołać słowa Stanisława Dróżdża (1939-2009) - głównego polskiego twórcy tego nurtu ${ }^{36}$, który doskonale scharakteryzował jego prerogatywy:

poezja konkretna polega na wyizolowaniu, zautonomizowaniu słowa. Wyizolowaniu go z kontekstu językowego, wyizolowaniu go także z kontekstu rzeczywistości pozajęzykowej, żeby słowo jak gdyby samo w sobie i dla siebie znaczyło. W poezji konkretnej forma jest zdeterminowana treścią, a treść formą. Poezja tradycyjna opisuje obraz. Poezja konkretna pisze obrazem ${ }^{37}$.

Tak rozumiana poezja konkretna to „twórczość pomiędzy poezją i malarstwem” - jak stwierdzono w 1965 roku w tytule oraz katalogu wspomnianej już wystawy „Between Poetry and Painting”38. Podstawowymi budulcami utworów omawianego nurtu stają się znaki językowe, przestrzeń i barwa. Pismo, którego najistotniejszą funkcją jest utrwalanie i przekazywanie różnego rodzaju tekstów, zyskuje w tym ujęciu nowe znaczenie i z narzędzia staje się surowcem artystycznym, materiałem zarówno semantycznym, jak też wizualnym ${ }^{39}$. Do wybitnych reprezentantów malarskich tego nurtu można zaliczyć Theo van Doesburga, Maxa Billa czy Włochów związanych z ruchem Movimento arte concreta (MAC) - Atanasio Soldatiego, Gillo Dorflesa, Bruno Munariego, Gianniego Monneta ${ }^{40}$.

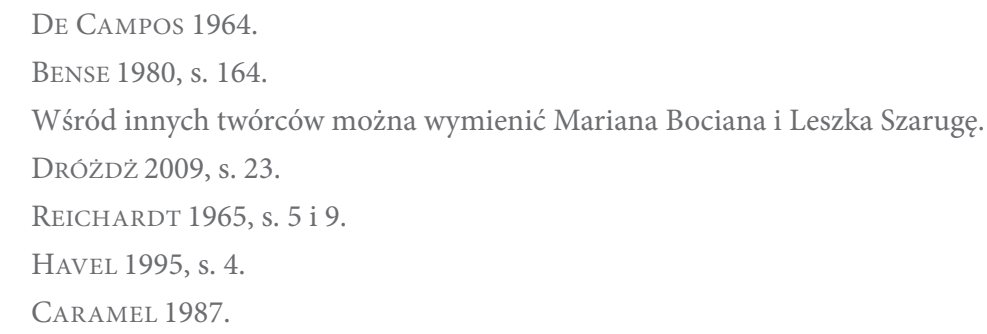


Jak wspomniałam, Dróżdż należał do mistrzów gatunku nazywanego poezją konkretną ${ }^{41}$. Ponieważ miał polonistyczne wykształcenie i niezwykły matematyczny umysł oraz intuicję grafika projektanta, jego dzieła doskonale oddają owo usytuowanie "pomiędzy poezją a malarstwem”. Artysta operując czarnymi literami, cyframi, znakami przestankowymi, ale też całymi czasownikami czy przysłówkami, przeobrażał je w samodzielne byty, a nawet w trójwymiarowe formy, tworząc instalacje przestrzenne w pomieszczeniach galerii. Doskonałym przykładem takiej aranżacji jest konstrukcja Między (1977/2004, MOCAK, Kraków). Instalację tworzy wolnostojące, zamknięte pomieszczenie o wymiarach 3 na 5 na 4,5 metra z wejściem umieszczonym po lewej stronie ściany. Wszystkie płaszczyzny - ściany, podłoga, sufit - są białe i pokryte czarnymi literami, które wyraźnie odcinają się od podświetlonego tła. Litery umieszczono w regularnie rozplanowanych poziomych i pionowych rzędach. Część z nich została obrócona pod kątem prostym względem osi pionowej lub poziomej. Choć dobór liter może wydawać się przypadkowy, to jednak artysta wybrał jedynie te znaki, które wchodzą w skład słowa „między”. Jak twierdzi krytyk sztuki Monika Małkowska, „w rezultacie powstało pudełko, w którym widz tracił poczucie skali, kierunków, odległości. Całym sobą, fizycznie odbierał sens słowa między"42.

Zdarzało się też, iż Dróżdż wzbogacał swoje prace o czwarty wymiar, czyli czas. Przykładem może być obraz zatytułowany Klepsydra (projekt z 1968 roku). To poemat typograficzny, w którym układ i wielkość czcionek tworzą wzmocniony przekaz semantyczny. W tym przypadku kształt zegara piaskowego został ułożony ze słów „będzie, jest, było". Słowo ,jest” znajduje się w centrum kompozycji i pozostaje najmniejsze; czas przeszły („było”) i przyszły („będzie”) rozrastają się ku przeciwległym krawędziom jak cylindry w klepsydrze. Na podobnych zasadach powstawały inne wizualizacje słów. Zawsze rygorystyczne, utrzymane w czerni i bieli, zaprojektowane co do milimetra. Artysta nadał im własną nazwę „pojęciokształty” O trwałości problematyki prezentowanej w pracy Dróżdża świadczy fakt, iż w roku 2013 Klepsydra wykonana jako mural (autor Roman Rutkowski) znalazła się na elewacji tymczasowej siedziby Muzeum Współczesnego we Wrocławiu z okazji wystawy ruchu Slow Art, w zamierzeniu którego sztuka wymaga czasu, by można było się nią delektowaćc ${ }^{44}$.

\footnotetext{
${ }^{41}$ Z polskich artystów warto jeszcze wymienić takich twórców jak: Zbigniew Makarewicz, Barbara Kozłowska, Marzenna Kosińska, Wanda Gołkowska, Natalia LL, a także działania artystów związanych ze Studium Kompozycji Emocjonalnej (DAWIDEK-GrYGLICKA 2013).

42 MaŁKOWSKA 2010.

43 DRÓŻDŻ 1968, s. 74.

44 Dzień Wolnej Sztuki 2013, http://muzeumwspolczesne.pl/mww/edukacja/dzien-wolnej-sztuki-2013/ [dostęp: 30.12.2018].
} 


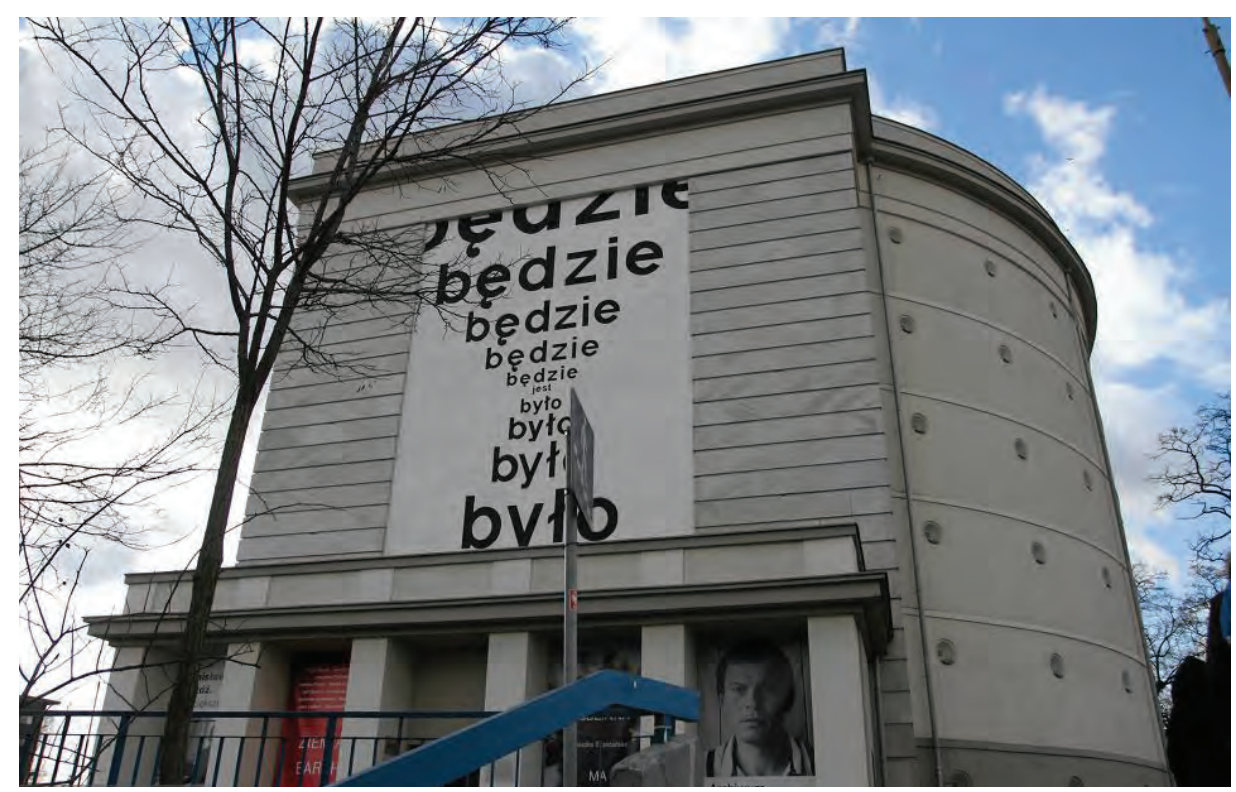

3. Stanisław Dróżdż, Klepsydra (było, jest, będzie), realizacja fragmentu pracy z 1967 roku na fasadzie Muzeum Sztuki Współczesnej we Wrocławiu, 2009, fot. Maciej Świerczyński

\section{Zupełnie nowe możliwości, czyli literatura elektroniczna ${ }^{45}$}

Najnowsza emanacja działań łączących ściśle poezję ze sztukami wizualnymi to literatura elektroniczna, czyli electronic literature ${ }^{46}$, określana też mianem cyfrowej (ang. digital literature) lub HTML ${ }^{47}$. W Polsce literatura elektroniczna jest relatywnie nową, młodą tendencją. Za początki poezji cyfrowej na świecie przyjmuje się jednak rok 1959, kiedy to wspomniany Max Bense zaproponował swojemu studentowi Theo Lutzowi zaprogramowanie pierwszego generatora do losowego wytwarzania elektronicznych obiektów ${ }^{48}$ - całkowicie stochastycznych poematów. Lata pomiędzy rokiem 1959 a 1995 uznane są za czas „pre-poezji cyfrowej”, która dopiero dzięki powstaniu powszechnego systemu WWW rozwinęła się na szerszą skalę i dotarła do większego grona odbiorców ${ }^{49}$. W Polsce nurt rozpoczyna się za pośrednictwem grupy artystycznej Perfokarta, która spotkała się na konwersatorium o cybernetyce w Instytucie Filozofii Uniwersytetu im. Adama Mickiewicza w Poznaniu w roku 2005 ${ }^{50}$. Obecne

\footnotetext{
45 Badacze poezji cyfrowej jak Chris Funkhouser, Friedrich W. Block, Roberto Simanowski czy Anna Katharina Schäffner sądzą, iż jest to trzeci etap rozwoju eksperymentów literacko-wizualnych. Pierwszym etapem byłaby poezja wizualna (od XVI wieku do początku XX wieku), a drugim poezja konkretna (druga połowa XX wieku) (PAWLICKA 2012a, s. 148).

46 Hayles 2011.

47 PaWŁowsKa/WendorfF 2017, s. 273-289.

48 PAWLICKA 2012b, s. 289.

49 BLOCK 2010.

50 PawŁowsKa/WendorfF 2017, s. 273-289.
} 
w sieci internetowej różne warianty tej odmiany literatury, jak: powieść hipertekstowa, powieść sieciowa, interactive fiction, narracje lokacyjne, dzieła kodowe (ang. codework), sztuka generatywna (ang. generative art) i poezja flaszowa (ang. flash poety), to jedynie pewne typy nowych gatunków literatury elektronicznej, wskazujące na różnorodność spotykanych tu form oraz na złożoność relacji zachodzących pomiędzy drukiem a literaturą cyfrową, oraz na szerokie spektrum estetycznych strategii możliwych do zastosowania na tym gruncie. To rodzaj w pewnym sensie zupełnie nowego dzieła piśmienniczego o cyfrowym rodowodzie (ang. born-digital), stworzonego za pomocą komputera i tam (nieomal zawsze) odczytywanego. A przy tym dzieła „o istotnych walorach literackich, które korzysta z możliwości i kontekstów wnoszonych przez stacjonarny lub podłączony do sieci komputer" ${ }^{31}$. Twórcy tego typu literatury, przeplatając elementy powieściowe z elementami gry, dodając interaktywne fikcje wzbogacają literaturę, o nowe techniki wspierane grafiką i animacją. W tych niezwykle urozmaiconych pod względem obrazu dziełach często elementy kompozycji pozostają w relacjach wyłącznie syntaktycznych, a znaczenie uzyskują dopiero, gdy odbiorca (widz lub czytelnik) zechce je połączyć i zinterpretować. Istniejąca w Chicago od 1999 roku organizacja Electronic Literature Organization (ELO) promuje i wspiera twórców związanych z tym nurtem, takich jak: Serge Bouchardon, Helen Burgess, Jeanne Hamming, Leonardo Flores, Jason Nelson, Anastasia Salter (przywołując tylko kilku), tworzących w różnych częściach globu ziemskiego e-literaturę ${ }^{52}$.

$\mathrm{Z}$ nowych form literackich na uwagę zasługuje collaborative fiction/writing - popularna na forach internetowych zabawa ze słowem, polegająca na dopisywaniu kolejnych słów/zdań do tekstu stworzonego przez poprzedników; np. Krótka historia Iwony Tramp Krystyny Kofty (2000/2001) czy Rok bez siedmiu minut (2001) Jerzego Pilcha. Projekty zakładały aktywne współuczestnictwo internautów w powstawaniu kolejnych części utworu, rozwijaniu poszczególnych wątków czy kształtowaniu postaci głównych bohaterów ${ }^{53}$. Powstają też bardzo liczne hiperteksty (termin stworzony przez Teda Nelsona w 1965 roku) o tekście rozbitym na fragmenty, które na wiele sposobów połączone są ze sobą odsyłaczami. Aleatoryczna, nielinearna i niesekwencyjna organizacja danych pozwalają odbiorcy na własne i wciąż nowe interpretacje, urzeczywistniając koncepcję Ecowskiego dzieła otwartego (wł. opera perta). Obok klasyków gatunku jak Michael Joyce, Mark Amerika, Stuart Moulthrop czy Shelley Jackson można wskazać interesujących polskich twórców (Robert Szczerbowski, Radosław Nowakowski, Sławomir Shuty $)^{54}$.

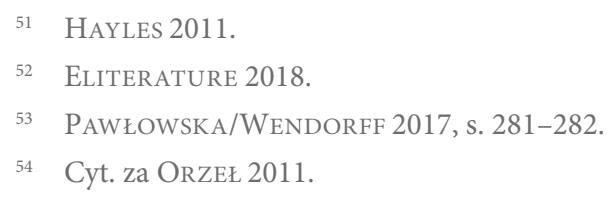


Stosowaną metodą są przekształcenia anagramowe, czyli permutacyjne zmiany tekstu w ramach własnego zbioru elementów. Analiza tego typu utworów wykazuje najsilniejsze ich zakorzenienie w poezji konkretnej. Dlatego nie wydaje się dziwne, co przytacza polska badaczka poezji cyfrowej Urszula Pawlicka, iż w 1992 roku Augusto de Campos w jednym z wywiadów wyraził nadzieję, że:

nowe eksperymenty multimedialne odpowiedzą na pytanie o to, co pozostaje jeszcze do odkrycia. Artysta, który jako jeden z pierwszych zaanimował swoje wiersze, podkreślił, że komputer zmaterializował i wzmocnił to, co było statyczne na papierze. „Verbivocovisual” poezji konkretnej, czyli próba połączenia komunikacji werbalnej i pozawerbalnej, zostaje dosłownie zrealizowana pod postacią grafiki, dźwięku i kinetyki. Augusto de Campos wprost stwierdził, że „ruch konceptualny stał się ruchem rzeczywistym"55.

Dobrym przykładem polskiej cyfrowej poezji konkretnej: może być utwór EMOH 2 (http://www.techsty.art.pl/magazyn/magazyn7/Wilmanski/emoh.html) Tomasza Wilmańskiego (ur. 1956). Jest to układ ośmiu rzędów, anagramowo ułożonych liter. Labirynt słowny stopniowo zanika poprzez animacyjne usuwanie poszczególnych liter, czemu towarzyszy dźwięk kojarzący się z rzucaniem czaru. Tajemnicze brzmienie pojawia się przy każdym odsłonięciu litery na czarnym tle, wchodzącej w skład hasła tytułowego, z kolei litery odczytane na wspak układają się w wyraz home. Animacja odsłania ukryte słowa, za każdym razem ułożone w innym miejscu.

Inne przykłady prac polskich artystów utrzymanych w konwencji cyfrowej poezji konkretnej to m.in. dzieło Zenona Fajfera Ars poetica (http://www.techsty.art. pl/magazyn3/fajfer/Ars_poetica_polish.html) oraz Romana Bromboszcza Wariacje na Kwadrat Magiczny i Rotator (http://variations.perfokarta.net/pl/).

W polskiej literaturze cyfrowej XXI wieku pojawiają się takie terminy jak: „liternet” Jerzego Ablewicza i „e-liberatura” Mariusza Pisarskiego. Liternet, zbitka słów literatura i Internet, obejmuje zarówno „literaturę w sieci”, czyli literaturę zdygitalizowaną, jak i „literaturę sieci”, czyli literaturę cyfrową. E-liberatura natomiast to termin nawiązujący do koncepcji liberatury propagowanej przez Katarzynę Bazarnik i Zenona Fajfera. Badacze owi do liberatury (od łacińskiego liber - „książka”, „,wolny”) zaliczyli utwory, których przekaz nie ogranicza się jedynie do sfery werbalnej, lecz dzieła, w których autor stara się przekazywać treści całą formą traktowanej podmiotowo książki: z jej budową, kształtem oraz sposobem zapisu tekstu, np. Oka-leczenie Bazarnik i Fajfera (https://www.youtube.com/watch?v=gsDdj4oFBFc\& feature $=$ youtu.be ${ }^{56}$. Natomiast e-liberatura to liberatura funkcjonującą $\mathrm{w}$ Inter-

\footnotetext{
55 PaWlicka 2012b, s. 290.

56 Wszystkie prace ilustracyjne związane z literaturą HTML można i należy zobaczyć w Internecie, bowiem tam zachowana jest animacja.
} 


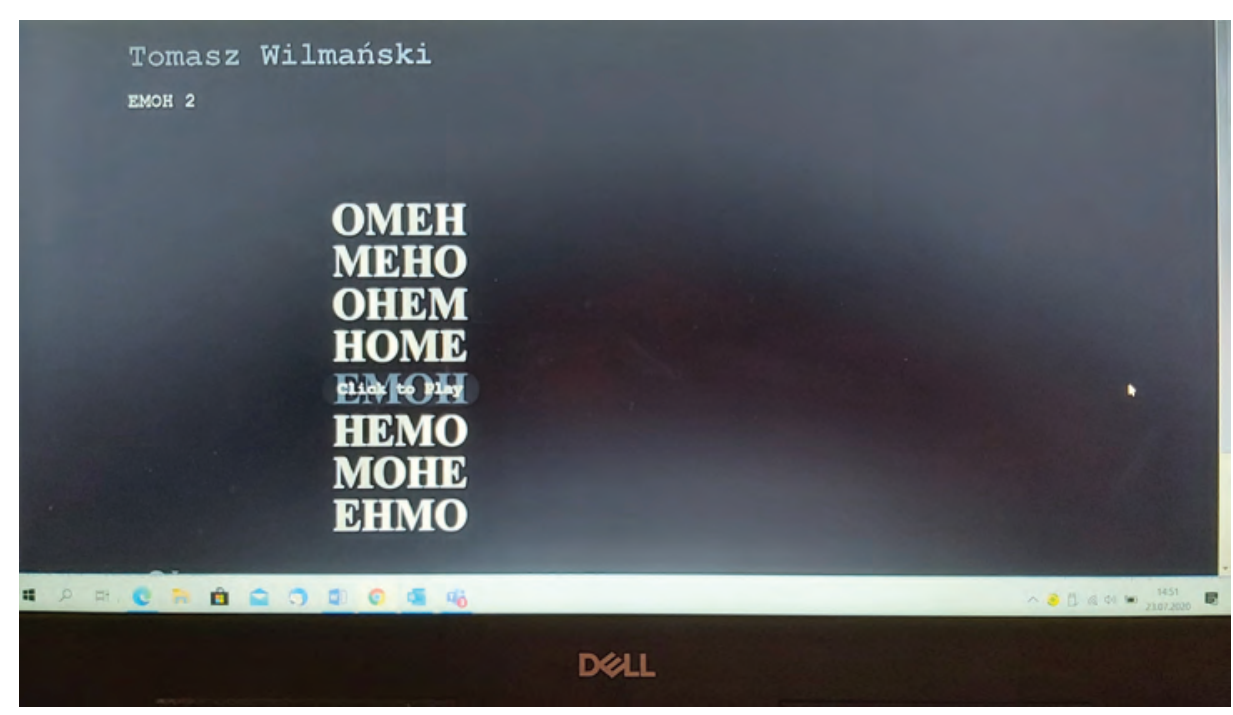

4. Tomasz Wilmański EMOH 2, na ekranie komputera autorki 2019

necie, czyli taka, dla której wirtualna przestrzeń, w jakiej została ukształtowana, staje się elementem konstytutywnym (np. Koniec świata według Emeryka Radosława Nowakowskiego ${ }^{57}$.

\section{Zakończenie}

Reasumując rozważania nad powiązaniami pomiędzy słowem a obrazem na przestrzeni ostatnich stu lat, można odnieść wrażanie, że tendencja, by łączyć te byty, nasila się. Literatura światowa przeszła długą ewolucję, która na przełomie wieków XIX i XX doszła do kulminacji w próbie wyzwolenia się z semantycznej konwencji słów i znalezienia nowych rozwiązań poetyckich i wizualnych. Wyrazy przestały być traktowe jako składnik zdania, a zaczęły jako samoistne byty układające się w obrazy. Otwarta została brama do prób i eksperymentów z wierszami, słowami i typografią pisma. W latach 50. i 60. XX wieku działania te wsparły spontaniczne eksperymenty z poezją wizualną i konkretną prowadzone nieomal na całym świecie. Kolejny krok to literatura elektroniczna anektująca do swych działań język HTML, środowisko World Wide Web, przeglądarki internetowe, a dalej narzędzia wyszukiwania informacji, system Web 2.0, portale społecznościowe aż po najnowsze koncepcje chmur informacyjnych. Artyści stworzyli zupełnie nowy bezpośredni kontekst dla wielorakich działań twórczych rozwijanych $\mathrm{z}$ wykorzystaniem technologii cyfrowych, w którym nielinearna i niesekwencyjna organizacja danych pozwala każdemu czytelnikowi współtworzyć obrazy zatopione w literaturze. Wizualne traktowanie

\footnotetext{
57 Bromboszcz 2011, s. 64.
} 
tekstu sprawia, że elementom językowym coraz częściej towarzyszą elementy graficzne, tak statyczne, jak i dynamiczne, co powoduje, iż w szeroko rozumianej przestrzeni publicznej coraz trudniej znaleźć takie komunikaty, które ograniczałyby się tylko do elementów czysto pisemnych. Nie sposób zaprzeczyć, że granica między tym, co językowe, a tym, co obrazowe, staje się coraz bardziej płynna, a w niektórych przypadkach ulega wręcz zatarciu.

\section{Bibliografia}

BENSE 1980 - Max Bense, Świat przez pryzmat znaku, tłum. Jan Garewicz, Warszawa 1980.

BLOCK 2010 - Friedrich W. Block, How to Construct the Genre of Digital Poetry, 2010, http://www. netzliteratur. net/block/digitaI_poetry.pdf [dostęp: 20.09.2019].

Boyé 1926 - „Dom pod pijanemi gwiazdami” Futuryzm i F. T. Marinetti, „Wiadomości Literackie”, 10 października 1926.

Bromboszcz 2011 - Roman Brambosz, Poezja cybernetyczna, hipertekst, liberatura, poezja neolingwistyczna. Geneza i struktura nowych zjawisk w literaturze polskiej, [w:] Od liberatury do e-literatury, red. Ewa Wilk, Maria Górska-Olesińska, Opole 2011, s. 60.

Caramel 1987 - Luciano Caramel, Movimento Arte Concreta 1948-1958, Modena 1987.

Cendrars 2006 - Blaise Cendrars, La Vie, le Verbe, l'Écriture, Paris 2006.

CHwistek 1920 - Leon Chwistek, Wprowadzenie, [w:] Tytus Czyżewski, Zielone oko. Poezje formistyczne. Elektryczne wizje, Kraków 1920, s. 5.

CHWISTEK 1921 - Leon Chwistek, O poezji, [w:] Nuż w brzuchu 2 jednodńuwka futurystuw wydańe nadzwyczajne, Krakuw-Warszawa 1921.

Compos 1964 - Augusto De Campos, Olho por olho, 1964, https://www.theguardian.com/artanddesign/gallery/2017/apr/07/masterpieces-concrete-poetry-pictures-getty-center-ian-hamilton-finlay-augusto-campos [dostęp: 28.09.2019].

DAwIDEK-GRYGliCKa 2013 - Małgorzata Dawidek-Gryglicka, Historia tekstu wizualnego. Polska po 1967 roku, Kraków 2013.

DRÓŻDŻ 1968 - Stanisław Dróżdż, Pojęciokształty, „Odra” 1968, nr 12, s. 74.

Dróż̇ż 2009 - Stanisław Dróżdż, Stanistaw Dróżdż. Początekoniec. Pojęciokształty. Poezja konkretna. Prace z lat 1967-2007. Katalog wystawy, red. Ewa Łubowicz, Wrocław-Warszawa 2009.

Eliterature 2018 - Eliterature, http://eliterature.org/people/ [dostęp: 20.12.2018].

GŁowiŃsKi 1998 - Michał Głowiński et al., Stownik terminów literackich, Wrocław 1998.

GOMRINGer 1978 - Eugen Gomringer, From Line to Constellation, transl. Mike Weaver, [w:] Concrete Poetry: A World View, red. Mary Ellen Solt, Bloomington 1978.

HAMmer 1991 - Victor Hammer et al., William Morris and His Heirs: A Kelmscott Centennial, Minneapolis 1991.

Havel 1995 - Vaclav Havel, Antikody, Wrocław 1995.

HAYLES 2011 - Katherine N. Hayles, Literatura elektroniczna: czym jest?, cz. 1, tłum. Sonia Fizek, Marcin Pisarski, „Techsty 7” 2011, nr 1, http://www.techsty.art.pl/magazyn/magazyn7/literatura _elektroniczna_czym_jest_1.html [dostęp: 9.12.2018]. 
Hose/SCHenker 2015 - Hose Martin, Schenker David, A Companion to Greek Literature, Chichester 2015 .

J.L. 1922 - J.L., „Lucifer” 1922, nr 2-4, s. 34.

LEWANDOWSKA 1966 - Bożena Lewandowska, U źródeł grafiki funkcjonalnej w Polsce, [w:] Ze studiów nad genezy plastyki nowoczesnej w Polsce, red. Juliusz Starzyński, Wrocław-WarszawaKraków 1966, s. 192-283.

Mallarmé 1890 - Stéphane Mallarmé, Kryzys wiersza, tłum. Ewa Dorota Żółkiewska, [w:] Stéphane Mallarmé, Wybór poezji, red. Adam Ważyk, Warszawa 1980, s. 89.

Mallarmé 2005 - Stéphane Mallarmé, Rzut kośćmi nigdy nie zniesie przypadku, tłum. Tomasz Różycki, red. Katarzyna Bazarnik, Zenon Fajfer, Kraków 2005.

MaŁKowsKa 2010 - Monika Małkowska, Pojęciokształty Stanisława Dróżdża, czyli gra z tajemnica losu, „Rzeczpospolita” 2010, nr 12, s. 48.

MARINETTI 1913 - Filippo Tommaso Marinetti, Distruzione della sintassi - Immaginazione senza fili- Parole in libertà, Maggio 1913.

MiczKa 1994 - Tadeusz Miczka, Czas przyszły niedokonany. O włoskiej sztuce futurystycznej, wydanie drugie uzupełnione, Katowice 1994.

Orzę 2012 - Paweł Orzel, Hiperteksty literackie. Literatura i Nowe Media, dwutygodnik.com. strona kultury, nr 12 (2012), https://www.dwutygodnik.com/artykul/2936-hiperteksty-literackie-literatura-i-nowe-media.html [dostęp: 20.09.2019].

PAWLICKA 2012a - Urszula Pawlicka, Ruch jako podstawa materializacji cyfrowej poezji konkretnej, „Zagadnienia Rodzajów Literackich” 2012, t. 55, z. 2, s. 282-306.

PAWlicka 2012b - Urszula Pawlicka, (Polska) poezja cybernetyczna. Konteksty i charakterystyka, Kraków 2012.

PAWlicka/PodgóRni 2012 - Urszula Pawlicka, Łukasz Podgórni, Cyfrowe Zielone Oko. Adaptacja poezji formistycznej Tytusa Czyżewskiego, „Ha!art” (2012), http://www.ha.art.pl/wydawnictwo/ katalog-ksiazek/2526-cyfrowe-zielone-oko-adaptacja-poezji-formistycznej-tytusa-czyzewskiego.html [dostęp: 20.09.2019].

PawŁowska/Wendorff 2017 - Aneta Pawłowska, Anna Wendorff, From Sign to Word in Contemporary Polish "HTML Literature”. Post-Avant-Garde Heirs of Modernist Typography, „Art Inquiry" 2017, nr 19, s. 273-289.

Reichardt 1965 - Reichardt Jasia, Between Poetry and Painting, London 1965.

Richter 1983 - Hans Richter, Dadaizm. Sztuka i antysztuka, tłum. Jacek S. Buras, Warszawa 1983.

RYPSON 1989 - Piotr Rypson, Obraz słowa. Historia poezji wizualnej, Warszawa 1989.

SobIERAj 2017 - Sławomir Sobieraj, Wokół formizmu poetyckiego Tytusa Czyżewskiego, „Teksty Drugie" 2017, nr 3, s. 172-184.

ŚNIEDZIEWSKI 2010 - Piotr Śniedziewski, „Rzut kośćmi” Mallarmégo - od oralnej metafory milczenia do piśmiennej metafory bieli, „Teksty drugie” 2010, nr 1-2, s. 193-207.

Turowski 1973 - Andrzej Turowski, Listy Władysława Strzemińskiego do Juliana Przybosia z lat 1929-1933, „Rocznik Historii Sztuki” 1973, t. 9, s. 223-293.

WAT 1990 - Aleksander Wat, Mój wiek. Pamiętnik mówiony, rozmowy prowadził i przedmową opatrzył C. Miłosz, Warszawa 1990.

WeIBel 2005 - Peter Weibel, Beyond Art: A Third Culture: A Comparative Study in Cultures, Art and Science in $20^{\text {th }}$ Century Austria and Hungary, Wien-New York 2005.

WiercińsKa 1986 - Janina Wiercińska, Szuka i książka, Warszawa 1986.

Zmiana Pola Widzenia 2014 - Zmiana pola widzenia, red. Paulina Kurc-Maj, Łódź 2014. 


\section{Visual literature, visuality of literature - a review of contemporary phenomena and trends}

\footnotetext{
$\mathrm{T}$

he aim of the article is to present a review of the most important trends that the literary text on visual values has been subject to in the last century. The starting point was the turn of the $19^{\text {th }}$ and $20^{\text {th }}$ centuries, when under the influence of avant-garde artists (Guillaume Apollinaire, Stéphane Mallarmé) there were changes in the perception of the semantic meaning of poetry, which led to a situation in which the text's visual structure became relevant (the works of.in.: FT Marinetti, T. Czyżewski, L. Chwistek). In the period immediately after World War I and in the inter-war period of the great avant-garde, artists associated with dadaism and the Polish group "a.r" showed interest in modern typography. Another important moment in the mutual relations of text and visual arts is the 1960s and 'concrete poetry' (E. Gomringer, brothers de Campos and S. Dróżdż, creating so-called 'conceptual shapes'). In the $21^{\text {st }}$ century, the emanation of activities that closely connect poetry with visual arts is electronic literature, referred to as digital or HTML, and liberature (K. Bazarnik, Z. Fajfer, R. Nowakowski).
}

Keywords: typography, avant-garde, liberature, $20^{\text {th }}$ century Polish art, electronic literature. 